\title{
Collaborative Writing in a Third Language: How Writers Use and View Their Plurilingual Repertoire During Collaborative Writing Tasks
}

\author{
Caroline Payant \\ Université du Québec à Montréal \\ Zeina Maatouk \\ Université du Québec à Montréal
}

\begin{abstract}
Recent years have witnessed major development in plurilingual pedagogies which support the use of learners' repertoire of languages in language learning contexts (Payant \& Galante, 2022; Piccardo, 2013). However, little research has been undertaken to examine adult plurilingual learners' perceptions towards the use of their languages during authentic collaborative writing tasks and contrasted these views with their actual behaviours. In this case study, six plurilingual adult learners of English in a Canadian university with three unique L1s (Romanian, Russian, Spanish) completed two collaborative writing tasks on two separate occasions. Each dyad shared the same linguistic profiles and were encouraged to draw on their entire repertoire to complete the tasks. Semi-structured interview data shows differing levels of openness towards L1 and L2 (French) use during language-learning writing tasks. The analysis of the interaction confirms multiple uses for the L1; however, the L2 was seldom observed during interactions. The findings are discussed from a plurilingual lens and pedagogical implications are discussed.
\end{abstract}

\section{Résumé}

Récemment, nous observons un essor important des pédagogies plurilingues qui soutiennent l'utilisation du répertoire langagier des apprenants des langues secondes et additionnelles (Payant et Galante, 2022; Piccardo, 2013). Cependant, peu de recherches se sont penchées sur les perceptions des apprenants adultes plurilingues à l'égard de l'utilisation de leurs langues lors de tâches d'écriture collaborative pour ensuite comparer celles-ci à leurs comportements lors des interactions. Dans cette étude de cas, six apprenants adultes plurilingues de l'anglais ayant trois langues maternelles différentes (roumain, russe, espagnol) ont réalisé deux tâches d'écriture collaborative, à deux occasions distinctes. Chaque dyade partageait le même profil linguistique et a été encouragée à puiser dans son répertoire pour accomplir les tâches. Les données d'entretiens semi-structurés montrent des niveaux différents d'ouverture à l'utilisation de la L1 et de la L2 (français) pendant les tâches d'écriture pour l'apprentissage de l'anglais. L'analyse des interactions des dyades confirme des utilisations multiples de la L1 ; cependant, la L2 a rarement été utilisée pendant les interactions. Nous discutons des résultats dans une optique plurilingue et soulignons les implications pédagogiques. 


\section{Collaborative Writing in a Third Language: How Writers Use and View Their Plurilingual Repertoire During Collaborative Writing Tasks}

\section{Introduction}

For some, the terms bilingualism and multilingualism conjure up images of individuals who have native competence in two or more linguistic systems and a $b i$ /multilingual speaker is viewed as the sum of multiple monolingual native speakers (Grosjean, 2008). A bilingual or multilingual speaker who cannot demonstrate mastery of multiple languages is perceived negatively and described as being lazy or lacking education (Grosjean, 2008). This is a deficit view of multilingualism, one that is, unfortunately, dominant across social and educational contexts (Cummins, 2007). From this viewpoint, learners are expected to develop native-like competence in each independent linguistic system. In an attempt to achieve this goal, second language (L2) educators have endorsed monolingual teaching approaches that promote target-language use only (Lin, 2013) with a native-speaker model in mind for decades.

In the field of education and applied linguistics, there has been a shift in how multilingualism is conceptualized and we now regularly speak of plurilingualism and plurilingual competence (e.g., Coste et al., 2009; Taylor \& Snoddon, 2013). From a plurilingual lens, scholars and practitioners challenge the idea that languages are discrete systems that should be kept apart in social and educational settings and recognize that there will always be variation in language proficiencies within an individual's linguistic repertoire. Scholars and practitioners maintain that plurilingual speakers are able to draw freely on their partial knowledge of various linguistic systems to communicate (Piccardo, 2013); however, there are some who do not always believe that having multiple languages is an asset (Haukås, 2016) and learners may not always feel empowered to draw on their rich repertoire in contexts which promote target-language use only (Galante, et al, 2020).

With this shift towards plurilingualism and plurilingual competence, empirical questions relating to how plurilingual speakers deploy their linguistic knowledge in social and language learning contexts have been put forward. In the context of education, researchers are reporting on teachers' practices and perspectives in relation to plurilingualism (Dault \& Collins, 2016; Galante, 2018a; Haukås, 2016; Woll, 2020) and on adult learners' perspectives (Dault \& Collins, 2017; Galante, 2020). Although there is support for the use of students' plurilingual repertoire during classroom-based interaction, there is a paucity of research from the learners' perspectives exploring the use of their repertoire when completing authentic writing tasks and the purposes for navigating between their languages during these. This case study with six plurilingual speakers contributes empirical evidence of how adult learners of English (1) perceive the benefits/challenges of using their larger linguistic repertoire during the completion of collaborative writing tasks and (2) engage with their repertoire of languages during the completion of writing tasks. Data for this study came from individual interviews and is supported by interaction data collected during a two-day writing task. 


\section{Plurilingualism and Plurilingual Pedagogies}

Plurilingualism, introduced in Europe more than two decades ago (Coste et al., 2009), promotes the use and learning of multiple languages to improve mobility and communication between individuals (Garcia \& Otheguy, 2020). From this lens, knowledge of languages forms a dynamic system: languages are known to interact and are characterized as having soft boundaries (Lin, 2013; Piccardo, 2013, 2019). In other words, it is not uncommon for speakers to combine linguistic elements from multiple languages during interactions (Cenoz \& Gorter, 2013). From a plurilingual lens, individuals' partial knowledge in a repertoire of languages is viewed positively (Moore \& Gajo, 2009; Piccardo, 2013). This knowledge gives learners the choice to draw on their entire repertoire or on a subset of their repertoire (Canagarajah, 2011). Lüdi and Py (2009) maintain that "one finds a choice of languages which is rigid or variable, according to social rules, participant resources, habits and the degree of control" (p. 161).

Pedagogical approaches that oppose dominant monolingual ideologies are permeating educational settings worldwide, but primarily with adult learners studying dominant languages (e.g., English, Spanish) (Galante, 2018b, 2020; Marshall, 2019; Marshall et al., 2019; Piccardo, 2013; Taylor \& Snoddon, 2013; Woll, 2020). Pedagogical practices that embrace the core principles of plurilingualism reject target-language-only policies (Coste et al., 2009; Leonet et al., 2020). Plurilingual pedagogies encourage learners to use and draw parallels between languages. This supports the development of their own awareness of languages systems through explicit reflections (Oliveira \& Ançã, 2009). As Armand (2012) explains, plurilingual pedagogies "create a positive classroom climate, open to linguistic and cultural diversity, that allows students to mobilize, confront, use their knowledge and language skills in different languages and actively engage in the acquisition of new knowledge" (p. 49).

Adult language learners have mostly been exposed to monolingual pedagogies and numerous language programs continue to teach an additional language without referring to any other languages (Cenoz \& Gorter, 2013). Learners are still often being reminded to function monolingually, namely, to avoid first language (L1) use and to leave their knowledge of other languages outside the learning environment. This creates the illusion that each language system can be isolated and that hard boundaries exist between them. In practice, teachers avoid making references to additional languages or allowing learners to draw on their L1. To counter these dominant views, plurilingual pedagogies need to become regular practice in language learning contexts (Castellotti \& Moore, 2005). Teachers and learners alike can benefit from becoming more aware of how adult learners who have primarily received monolingual instruction perceive and access their knowledge in a repertoire of languages. In what follows, we report on empirical research which has closely examined learners' perception towards their plurilingualism.

\section{Learners' Perceptions Towards the Use of a Plurilingual Repertoire}

How learners perceive their plurilingual identity and language use has received some attention across a variety of instructional contexts. In their exploratory case study with two adolescent Ukrainian students attending Portuguese schools, Oliveira and Ançã (2009) sought to uncover whether their participants believed that having a plurilingual identity benefited their language development and increased their general awareness of 
languages. Language awareness was operationalized as the "ability they have to think about language (mother tongue or foreign language) and to verbalize those considerations" (Ançã \& Alegre, 2003, as cited in Oliveira \& Ançã, 2009). Semi-structured interview data revealed that the participants held positive views concerning their plurilingual repertoires and that they considered their various languages to serve complementary functions. They were also aware that their proficiency in their multiple languages was asymmetrical and, in the case of one participant, that their perceived proficiency can change over time. The authors emphasized the importance for pedagogues to actively engage students in reflections about their linguistic repertoire, their language histories and language development. They further encourage implementing crosslinguistic and contrastive approaches to harness their students' awareness of languages.

As part of her doctoral research, Payant (Payant, 2018; Payant \& Kim, 2015, 2019) examined the mediating functions of native and non-native languages during the completion of a series of collaborative tasks. The author reported specifically on Mexican learners' perception towards native and non-native language mediation in a French as a third language (L3) language learning context. Learner perception data were collected on four occasions, following the completion of four types of pedagogical tasks. Questions prompting information about their language use during task-based interactions demonstrated that the participants valued having a larger linguistic repertoire. She explained how Spanish (L1) played an important role in supporting their learning and explained how it allowed for linguistic reflections and crosslinguistic comparisons with French (L3) over one 16-week academic semester; however, the participants did not agree on how much L1 mediation should be permissible in a language-learning context. Some attributed benefits to also mediating the task completion via English (L2) in this foreign language context; however, this was not shared by all the participants. Finally, the participants explained that their larger repertoire was useful for social functions, namely, building rapport and engaging in language play (e.g., making jokes).

As part of her doctoral research, Galante $(2019,2020)$ implemented a plurilingual approach with English for Academic Purposes (EAP) teachers $(\mathrm{N}=7)$ and their students in a Canadian context. Over a 4-month period, learners completed 10 unique plurilingual tasks. Galante reported on three tasks that sought to tap into students' creative representations of languages and cultures (Galante, 2019) and on the associated challenges of completing three different plurilingual tasks (Galante, 2020). The qualitative analysis of students' diary entries, classroom observations, and artefacts revealed that through these creative outlets, they became more aware of their plurilingual identities and better understood how their linguistic and cultural resources were central to their identities. Moreover, participants appreciated that their linguistic repertoires were being validated in a formal learning context; however, they found it difficult to engage in meaning-making activities in multiple languages. They also struggled to know when to shuffle between their languages given that they do not always know who shares linguistic knowledge with them.

In summary, the emerging empirical evidence provides support for the implementation of plurilingual approaches from the learners' perspective. How learners exercise their plurilingual competence during collaborative tasks in language classrooms has also been the object of empirical work that has shown that languages can serve unique and complementary functions during task performance. We now turn to research that closely examined the various functions associated with plurilingual learners' use of languages found in their repertoire of languages. 


\section{Plurilingual Repertoire and Language Functions}

Building on the notion that there are soft boundaries between languages, a number of researchers have closely examined the synergies between two or more languages. When learning an L2, for instance, there is robust evidence that learners draw on their mother tongue to mediate the completion of oral and written tasks (Al Masaeed, 2016; Antón \& DiCamilla, 1998; Canagarajah, 2011; Kobayashi, 2003; Ma, 2019; Storch \& Wigglesworth, 2003; van Weijen et al., 2009). It has been found that the L1 plays a number of important roles for L2 learners, including, supporting language discussions (e.g., grammar, vocabulary, spelling), content discussions (e.g., generating ideas), taskrelated functions (e.g., clarifying task requirements, assigning sub-tasks), and social functions (e.g., building rapport). The linguistic makeup of language classrooms is quite complex and many learners are in the process of learning a language beyond their second. Researchers are now also exploring the functions of the languages of the repertoire during task completion with multilingual writers.

When completing individual writing tasks in an L3, there is robust evidence that the L1 plays the same core functions as reported in the L2 literature, namely language, content, task management, and social functions (Angelovska, 2018; Gunnarsson, 2019; Mieszkowska \& Otwinowska-Kasztelanic, 2015; Payant, 2020; Tullock \& FernándezVillanueva, 2013). With multilingual learners, the L1, and also the L2, can mediate the completion of the tasks and serve important functions which illustrates the soft boundaries between all languages. These researchers have demonstrated that the L2 tends to play one dominant function, namely, lexical deliberations. In Angelovska (2018), however, their adult participants frequently turned to their L2 German rather than their L1 while completing their English L3 writing task. In this study, the participants had immigrated to Germany and had received formal German instruction since age 10 which may explain the heavier L2 reliance. This suggests that context and L2 experience may influence how resources are deployed during interaction.

What unfolds during collaborative writing tasks with L3 adult learners remains underexplored. To date, there is some evidence that learners turn to their shared L1 to discuss language, content, and the task requirements; however, during spontaneous interactions, there is less evidence that participants draw on their shared L2. Payant and Kim (2015) reported on Mexican foreign language learners' use of English (L2) and French (L3) during task-based interaction. They identified four main categories for language use, namely, task-related, content-related, language-related, and task performance. They found that the participants relied primarily on the target language and that the L2 was seldom used by the participants and tended to serve lexical functions within the language-related category. Extending this line of research, Kim et al. (2020) reported on Korean foreign language learners' use of Chinese (L1) and English (L2) during task-based interactions in the United States of America. Interaction data shows important differences in the quantity of L1 and L2 use between the two dyads. One dyad relied significantly more on their L1 (47.9\%) than on their shared L2 (8.8\%). Chinese was used primarily to resolve language functions. The other dyad used their shared L1 less than $1 \%$ of the interaction data and instead relied extensively on their L2 English (56\%), which again, served primarily language-related functions. They explained that proficiency levels and perceived distance between the languages mediated each dyad's performance data. To the best of our knowledge, these are the only two studies that have closely examined how 
plurilingual speakers use their various languages during collaborative writing tasks in their newer language. In summary, there is unequivocal evidence that learners' repertoires are activated during individual and collaborative language tasks and that this knowledge supports their language learning efforts. However, it is important to further probe how learners across various education and social settings perceive and enact their plurilingualism.

\section{Present Study}

In the field of language education and applied linguistics, research focusing explicitly on speakers of three or more languages is on the rise. Given the fact that the study of L3 learning is more complex than the study of L2 learning due to factors such as age of acquisition, learning trajectories, learner proficiency, and language typology (Jessner, 2008), it is critical that we continue exploring how plurilingual speakers perceive and exercise their plurilingual competence spontaneously during learner-learner interaction. The present study contributes valuable information about how adult learners of English (L3), who identify as learners of French, mediate the completion of collaborative tasks. Specifically, this research explores whether adult learners who have experienced monolingual pedagogies are open to plurilingual pedagogies and whether their perspectives are in line with their actions during collaborative work.

The present exploratory case study conducted in a plurilingual city in Canada was guided by two overarching objectives, namely, to uncover whether L3 learners perceive their linguistic repertoire to be an asset during collaborative writing tasks and to examine their use of their linguistic resources during said tasks. The two research questions that guided the present study are:

1. What are the participants' perceptions towards the use of their linguistic repertoire during two collaborative writing tasks?

2. How do participants use their language resources during collaborative writing tasks?

\section{Methodology}

\section{Context of the Study and Participants}

In Quebec, Canada, learning French is necessary for newcomers' socio-economic integration and the Quebec government offers free French language courses. To continue developing French language skills or to develop additional language knowledge, individuals can pursue studies in language schools/programs. The present study was conducted in a language school for adults studying English through formal classes who were still in the process of developing their French competencies, albeit informally.

We recruited six intermediate learners enrolled in an Academic English Program housed in a French-medium university (see Table 1). We formed three dyads with members sharing the same linguistic profiles. The participants' L1s were Russian $(n=2$; females) Spanish ( $n=2$; males), and Romanian ( $n=2 ; 1$ female/1 male). They ranged in age from 34 to $51(\mathrm{M}=40.5 ; S D=5.9)$. Although they were all learning English in Canada at the time of the study, they also had experiences learning French and English in their home 
countries and/or in Canada and still considered their French to be developing. Overall, the participants reported having studied in English in their home country more than French; however, while in Canada they had more experience studying French compared to English: $\mathrm{M}=20.7$ months; $S D=9.5$ and $\mathrm{M}=8.8$ months; $S D=3.8$, respectively.

Table 1

Participant Profiles

\begin{tabular}{|c|c|c|c|c|c|c|c|}
\hline \multirow[t]{2}{*}{ Participant } & \multirow[t]{2}{*}{ L1 } & \multirow[t]{2}{*}{ Gender } & \multirow[t]{2}{*}{ Age } & \multicolumn{2}{|c|}{ English (months) } & \multicolumn{2}{|c|}{ French (months) } \\
\hline & & & & $\begin{array}{l}\text { Home } \\
\text { Country }\end{array}$ & Canada & $\begin{array}{l}\text { Home } \\
\text { Country }\end{array}$ & Canada \\
\hline Gabriel & Romanian & $\mathrm{M}$ & 42 & $0 *$ & 12 & 7 & 24 \\
\hline Polixenia & Romanian & $\mathrm{F}$ & 41 & 48 & 12 & 7 & 12 \\
\hline Olga & Russian & $\mathrm{F}$ & 34 & 84 & 6 & 5 & 10 \\
\hline Viktoriya & Russian & $\mathrm{F}$ & 37 & 144 & 3 & 1 & 24 \\
\hline Chucho & Spanish & M & 51 & 12 & 12 & 2 & 36 \\
\hline Gabriel & Spanish & M & 38 & 108 & 8 & 4 & 18 \\
\hline Mean & & & & 66 & 8.8 & 4.3 & 20.7 \\
\hline$S D$ & & & & 56.2 & 3.8 & 2.5 & 9.5 \\
\hline
\end{tabular}

Note: Gabriel reported 0 years of English study in his home country although some English instruction was required. All names are pseudonyms.

The aim of this exploratory study was to show how learners of English draw on their linguistic resources during collaborative writing tasks. With this particular aim in mind, we invited participants enrolled in intermediate English courses (i.e., B1-B2) to take part in the study. We asked participants to evaluate their own language proficiency. While this is not an objective measure of language proficiency, we were able to paint a portrait of their language profiles. As shown in Table 2, the participants had comparable self-reported French and English proficiencies, with one exception, Chucho, who reported a much lower French language proficiency.

Table 2

Self-Reports for French and English Language Proficiency

\begin{tabular}{lcccccc}
\hline & $\begin{array}{c}\text { English } \\
\text { Speaking } \\
\text { Level }\end{array}$ & $\begin{array}{c}\text { Writing } \\
\text { Level }\end{array}$ & $\begin{array}{c}\text { Reading } \\
\text { Level }\end{array}$ & $\begin{array}{c}\text { Speaking } \\
\text { Level }\end{array}$ & $\begin{array}{c}\text { Writing } \\
\text { Level }\end{array}$ & $\begin{array}{c}\text { Reading } \\
\text { Level }\end{array}$ \\
Gabriel & 6 & 6 & 7 & 8 & 7 & 8 \\
Polixenia & 5 & 6 & 7 & 8 & 7 & 9 \\
Olga & 7 & 8 & 8 & 7 & 6 & 8 \\
Viktoriya & 7 & 6 & 8 & 7 & 5 & 7 \\
Chucho & 3 & 3 & 5 & 6 & 6 & 9 \\
Gabriel & 5 & 7 & 8 & 7 & 8 & 8 \\
Mean & 5.5 & 6 & 7.2 & 7.2 & 6.5 & 8.2 \\
$S D$ & 1.5 & 1.7 & 1.2 & 0.8 & 1.0 & 0.8 \\
\hline
\end{tabular}

\section{Treatment Tasks}


For this study, we developed a two-day treatment task which included two collaborative writing components and two error correction components. For the first writing task, participants drafted a survey about the legalization of cannabis in Canada. First, each participant read one of two authentic articles that were retrieved from two reputable Canadian news outlets ( $~ 800$ words) and using this information, they collaboratively produced a survey with 10 open-ended questions which was published online (by the research team) to elicit the general public's opinion. Participants were instructed, in writing and orally, to draw on any of their languages during their interactions. The second writing task was a letter to the city mayor. First, the participants read the responses to the online survey and were then asked to summarize and present the findings from the survey to the mayor of Montreal.

In addition to completing the two main writing tasks, participants completed a crosslinguistic error correction task designed to increase their awareness of how their languages compare and to promote the use of their entire repertoire during these discussions. The research team underlined five erroneous forms from their written work and returned the written text with the indirect feedback to the participants. They were instructed to discuss the errors in any language, compare the target structures across their additional languages, and attempt to correct the error. For the treatment tasks, the participants worked in a small room and were instructed not to use any technology to encourage oral discussions: the research team conducted regular checks to see if they had questions and to ensure that they were not using their mobiles.

\section{Semi-Structured Interviews}

Each participant was interviewed once to share their perception towards the use of their repertoire during the tasks (They were asked to explain why they had (or had not) used their additional languages during the tasks, if they tried to make explicit connections during the tasks and asked about how their peer's use of additional languages made them feel. Finally, we also asked general questions about their use of their linguistic repertoire in language-learning contexts. For instance, we asked how they feel about using their repertoire or hearing other languages spoken during language courses.

\section{Procedure}

The data were collected in a laboratory setting. Each dyad met with the research team three times. The dyads were created based on the participants' linguistic profiles prior to the first meeting: learners had to share the same linguistic repertoire, but not necessarily the same proficiency in the L2. This particular configuration created greater opportunities for the participants to mediate the completion of the tasks using their entire repertoire. During the first meeting, participants were greeted by the research team and their consent to participate was obtained. For each phase of the study, the participants were reminded that they could use all their language resources to complete the tasks with their peers. To begin, the participants completed the reading (15 minutes) in a small quiet room and were invited to take notes, in any language, since they would need this information to complete the main survey creation task (30 minutes). The participants were given an instruction sheet that invited them to prepare a survey with open-ended questions. After this 30- 
minute activity, the research team read their survey and identified five erroneous forms in their text. The sentences which contained erroneous forms were underlined which forced the participants to revisit the entire sentence. Participants were given 15 minutes to complete the crosslinguistic error correction task. They were instructed to explain the error using their grammar knowledge of their first and second languages and to discuss these using their entire repertoire if needed. After this meeting, the research team obtained responses to the surveys created by each dyad from the general public $(\mathrm{N}=6)$, namely, graduate students in language education that were not aware of the research but knew members of the research team.

One week later, the dyads returned to the research lab and were given 15 minutes to read the responses to their survey. Following this joint reading task, they were instructed to report the major findings to the mayor by writing a letter. They were given 20 minutes to complete this letter. Similar to Day 1, following the writing task, the participants completed the error correction task. For the third, and final, visit, participants were invited to take part in a one-on-one interview which lasted approximately 25 minutes. Oral interactions were recorded during the collaborative writing tasks and during the interviews and were transcribed verbatim by two assistants. After this third visit, participants were given a $\$ 25$ gift card to the university bookstore.

\section{Data Analysis}

All output produced by the learners during the interviews and collaborative writing tasks was audio-recorded and transcribed verbatim ${ }^{1}$. To respond to our first research question, interview data were coded qualitatively by the research team. Typical of qualitative analysis, each interview transcript was read several times and preliminary ideas were noted in the margins of the transcribed text, which was then followed by a discussion of these preliminary codes, including but not limited to language functions, contexts and their appropriateness, language typologies, and attitudes. For the interaction data, we were interested in seeing how they used their repertoire to complete the tasks. We examined the functions of each language separately; however, the aim is not to argue for discrete systems. Rather, we use this information to show how knowledge of all languages forms an integrated system that can be used by plurilingual writers. We drew on previous research to operationalize the codes (Payant \& Kim, 2015; Storch \& Aldosari, 2013) and included language-related functions (metalinguistic explanations, grammar and vocabulary deliberations), meaning-related functions (generating ideas), and task-related functions (task management, clarifying ideas). In this study, the interaction data is used to illustrate the participants' perceptions in relation to their practices. For this reason, we did not quantify these functions but rather illustrate the range of functions.

\section{Findings}

This study sought to examine how learners perceived their linguistic repertoire and to determine how they used their linguistic resources during collaborative writing tasks. We first report on each dyad's perception towards their linguistic resources and corroborate these findings with interaction data. In this next section, we illustrate how the participants valued, to varying degrees, having a plural repertoire and show how these views do not always align with their actual practices. 


\section{Fluid Nature of Linguistic Repertoires During Collaborative Writing Activities}

\section{Polixenia and Gabriel}

\section{Reported Beliefs: Limiting Non-Target Language Use}

During their interviews, the two Romanian-speaking participants explained that they preferred to limit, even avoid, additional language use. Gabriel did not seem to understand the rationale for using additional languages. During the task completion, for instance, when reading the instructions that encouraged them to use all their language resources, he exclaimed in Romanian: "What do we gain if we write it in Romanian?". During the interview, he also discussed how using other languages should be done judiciously: "I think it's a good idea, but not every time. But sometimes, it's a good idea". Polixenia also appeared to prefer limiting additional language use and said: "In my opinion, I think even though we have this possibility to speak in our language or in French, it's a good idea. But for me, it's not good because I try to learn a foreign language [...] I try to think in the language I learn". Despite this, Polixenia explained that for vocabulary, she sometimes compared, in her mind, lexical items across languages: "Maybe anytime we choose a word in English and in my mind, I think in French is [sic] the same or similar in French? And can I use the words, they are similar in both?". Overall, however, she felt that English was typologically too distant from Romanian and from French: "In English, it's different grammatical rules than in French. We can't make comparisons between French and English [...]. I think there aren't any connection between our language and English $[\ldots] "$.

Despite these claims, both were found to shuffle between English and Romanian for multiple functions. Gabriel relied very frequently on his L1 compared to Polixenia. We also noted interesting patterns of L1 to L3 alternations, which we discuss below.

\section{Multiple Functions for the L1 During Learner-Learner Interaction}

Gabriel and Polixenia alternated between English and their L1 and we observed that the latter served a range of functions during the collaborative writing tasks, namely, to generate ideas, to discuss lexical ambiguities, to request clarifications or make comprehension checks, to provide error corrections, and to manage the task requirements (e.g., number of questions to produce, time management). We draw on one excerpt to illustrate how Gabriel naturally and effortlessly alternated between his L1 and the target language where the L1 served numerous functions. In Excerpt 1, Gabriel was trying to activate the word appropriate (see Excerpt 1). 


\section{Excerpt 1}

Multiple L1 Functions

\begin{tabular}{lll}
\hline Line & & Learner-Learner Interaction \\
\hline 1 & $\mathrm{G}:$ & $\begin{array}{l}\text { Do you believe that legal age... Do you believe the legal age. Is not e... } \\
\text { is not too, too... is... How to say it? In fact, you can say it straight and } \\
2\end{array}$ \\
3 & simple. Do you believe that... \\
4 & $\mathrm{P}:$ & $\begin{array}{l}\text { Legal age. } \\
5\end{array}$ \\
6 & That legal age is hum... opportune? No. Do you think that the legal age \\
7 & & $\begin{array}{l}\text { is reasonable. Legal age is... is good. Wait a second. Wait a minute. I } \\
\text { know how to say it. Age-appropriate. }\end{array}$ \\
\hline
\end{tabular}

Note: Italicized text is Romanian; bolded text is English

In Line 1, Gabriel first produced a yes-no question in English and translated this construction into Romanian. He then requested help (or a self-directed question) in Romanian and produced an answer to his question in Line 2, also in Romanian. In Line 5, he produced an L1 word still searching for the right English equivalent, repeated to produce a yes-no question (in Lines 5 and 6) and engaged in some self-directed speech to manage the task (in Lines 6 and 7) before eventually recalling the word appropriate in English. This excerpt is representative of their interactions during task performance such that the L1 played numerous functions, namely, language-related functions, meaningrelated functions, and task-related functions. We also observed that L1 use was more frequent in Gabriel's interactions compared to Polixenia's output.

\section{Juxtapositioning of L1 and L3 Structures}

During the survey writing task, we frequently observed the juxtapositioning of L1 and L3 question forms. Polixenia and Gabriel would first produce the target question in Romanian before proceeding to generate an L3 equivalent. We can observe this pattern in Excerpt 2 where Gabriel first produced the question in Romanian (see Line 1). After having established the idea in Line 1, he continued to produce an English equivalent. This was repeated in Lines 3 and 5.

\section{Excerpt 2}

Juxtapositioning L1 and L3 Structures

\begin{tabular}{|c|c|c|}
\hline Line & & Learner-Learner Interaction \\
\hline & G: & How... What do you think, how important are the risks? How important \\
\hline 2 & & No. How important the risks are in your opinion? How \\
\hline 3 & & important. How important is to know the risks? Do you know the risks? \\
\hline 4 & & How important. How important... How important is to be aware about \\
\hline 5 & & the risks. How important is to know all the risks? \\
\hline
\end{tabular}

Note: Italicized text is Romanian; bolded text is English

By verbalizing his thinking process, he engages in a recursive juxtapositioning between the L1 and the L3. It would appear as though the L1 is being used as a tool to reflect on the L3 question formation during the survey writing task. These occurrences of drawing on their knowledge of these two languages were frequent, however, the participants mentioned not 
engaging in them during the interviews, which suggests that they may not be aware of these behaviours.

\section{L2 Knowledge: Not Perceived as an Asset for English Learning}

The two participants did not perceive their French knowledge to be of much use in this context and we found limited evidence from their interactions that would suggest otherwise. We identified one explicit reference to French, where Polixenia drew Gabriel's attention to one lexical similarity between French and English, but it did not lead to sustained discussions about French form. As shown in Excerpt 3, Gabriel proposed the phrase Mental disorder development in Line 1 and Polixenia explained that, as in French, the word development was not needed.

\section{Excerpt 3}

Reference to the L2 During Interaction

\begin{tabular}{lll}
\hline Line & & Learner-Learner Interaction \\
\hline 1 & G: & Mental disorder development. because this includes them all. Mental... \\
2 & P: & $\begin{array}{l}\text { No development. It's like in French. So here it's that it is an obstacle to } \\
\text { the development of the brain. And here you say mental disorders } \\
3\end{array}$ \\
4 & & $\begin{array}{l}\text { development, it won't work. Mental disorders... } \\
5\end{array}$ \\
\hline
\end{tabular}

Note: Italicized text is Romanian; bolded text is English

We also identified some infrequent French lexical inserts, as shown in Excerpt 4. These were words that were simply integrated into their conversation demonstrating the fluid boundaries between languages but were not the object of discussion. It should be noted that they were not frequent in their interactions.

\section{Excerpt 4}

L2 Lexical Inserts

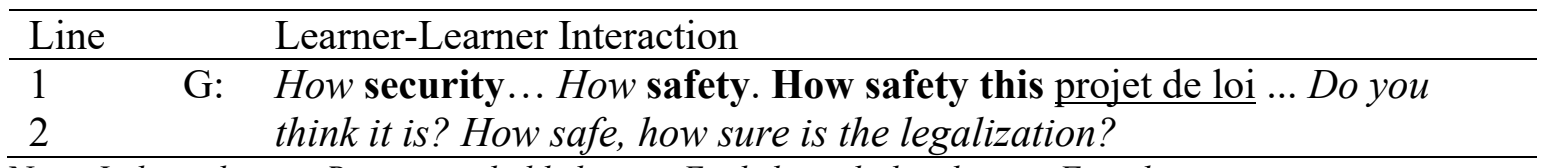

Note: Italicized text is Romanian; bolded text is English; underlined text is French

In summary, this dyad tended to make use of the L1 for a range of functions despite maintaining that it is best to function monolingually in a language course. This shuffling between the languages of the repertoire was quite fluid and was used to support their writing activities by way of L1-L3 juxtapositioning. We did not find evidence from the interview data or the interactions that L2 French knowledge was an important resource. On the contrary, when asked whether she drew on her L2 French, Polixenia explained that there are no comparisons to be made between French and English because "it's different rules, grammatical rules than in French". Rather than drawing on their holistic repertoire, namely all of the linguistic resources at their disposal, they engaged their selective repertoire which we operationalize as only drawing on some of the languages in their repertoire. 


\section{Olga and Vera}

\section{Divergent Reported Beliefs}

Olga and Vera had differing views regarding how their languages could be used to support their language learning efforts. Vera was very pragmatic about using her entire repertoire:

If I have already an equivalent in Russian, I will translate it and that's all. A table is a table. A coat is a coat [...]. It's very difficult for me, like for an adult who has already vocabulary, who has a base, to spend time working on new vocabulary without any base [...]. But on the base of understanding meaning, understanding the base of grammatical points, meaning of the words, like, vocabulary, I think it's important to use a different language.

During the task completion, we witnessed that Vera needed to draw on her L1 knowledge to generate a sentence in English. When trying to produce an English question, she exclaimed spontaneously in Russian: "First, we have to formulate it in Russian. I don't see the question, that's why I cannot formulate it in English [...] You see, we can't say it even in Russian that's why we have troubles formulating it in English. [...] in Russian we don't say like this. I mean it does not sound nice". This resembles the L1-L3 juxtapositioning frequently observed in Gabriel and Polixenia's data. For grammar, however, she believed that the typological distance between English and Russian discouraged the use of Russian for learning about grammar: "No, absolutely not, because grammar is very different" [...].

Olga, on the other hand, did not perceive her languages to be important resources for language learning. She discussed during her interview: "In my opinion, when you're studying a foreign language, you should never speak in your first language in class. I think it's negative". During their interactions, however, Olga was often found to engage with her peer using Russian. Maintaining good rapport with Vera was more important than maintaining target-language-only exchanges and therefore, she shuffled between English and Russian to accommodate her peer. She explained: "Really, I wanted to speak English. I don't want to speak Russian. [...] because I don't want to disturb her about Russian... but she wanted to speak Russian language and this why I accept and this why we are * continue but I prefer to speak English". Therefore, the choice to draw or not on a language was made in reference to the preferences of her peer, thus highlighting the social nature of these plurilingual exchanges.

With respect to their use of L2 knowledge, both participants explained that they only sometimes used the L2 as a reflective tool to help them become more aware of grammatical similarities between their languages. For instance, Olga explained how she compared English and French for grammar: "Rules in English [...] I am comparing with French syntax. Yeah, because it's a little bit the same, the structure, I think so". Similarly, Vera found French and English to be mutually beneficial for grammar. She explained: "I do comparison because some rules are general with French and English. In this situation, yes. If I find common points, for sure [...] If I have this rule already in my head in French, for sure, I will remember it quicker in English". Vera also shared that French knowledge contributed to academic vocabulary development: "Because some even academic words in 
English, in general, I knew in English thanks to French". We now illustrate how they drew on these linguistic tools during the task completion.

\section{Multiple Functions of the L1 During Interaction}

Similar to the Romanian-speaking participants, the L1 played numerous functions during this dyad's interactions. They also shuffled between their L1 and English to generate ideas, to discuss lexical ambiguities, to request clarifications, to check for comprehension, to provide feedback, and to manage the task requirements (e.g., number of questions to produce, time management). Throughout their interactions, we observed that Russian dominated the discourse. We illustrate these observed findings in Excerpt 5.

\section{Excerpt 5}

Multiple L1 Functions

\begin{tabular}{lll}
\hline Line & \multicolumn{2}{l}{ Learner-Learner Interaction } \\
\hline 1 & V: & Are cannabis and marijuana the same thing? \\
2 & O: & Yes, the same. \\
3 & V: & I learn so many new words... I will enrich my vocabulary. Who should \\
4 & & be responsible for the control about... How do you spell cannabis? \\
5 & O: & The ca.na.bis \\
6 & V: & double 'n'. Cannabis, for the control about cannabis use by \\
7 & & teenagers. We spell it like this? Ok. Let's move on \\
8 & O: & Yes Health Canada organizes festivals and advertises what's prohibited... \\
\hline
\end{tabular}

Note: Italicized text is Russian; bolded text is English; underlined text is French

Through their L1, they focused on language-related aspects (i.e., vocabulary in Lines 1 and 2; mechanics in Lines 4-6), on task-related aspects (e.g., commenting about learning in Line 3; managing the task in Line 7), and on meaning-related aspects (i.e., generating ideas in Line 8).

We did not uncover evidence of L1-L3 juxtapositioning during their interactions. Instead, we found that Vera and Olga engaged more frequently in metalinguistic discussions about grammar. In their interactions, we found that both initiated metalinguistic explanations using the L1. In Excerpt 6, Vera explained the difference between 'they' and 'their', drawing extensively on their shared L1. In Line 3, she explains that they need a sentence subject and continues to explain the function of they, in Line 4.

\section{Excerpt 6}

Metalinguistic Explanations

\begin{tabular}{lll}
\hline Line & & Learner-Learner Interaction \\
\hline 1 & V: & They. That means (harmful) on people's health or teenagers' health? In \\
2 & & this case, we should write they. They are people. Not theirs. Because if \\
3 & & we say theirs, it will be on people, but we need here a subject and these \\
4 & & are different persons \\
5 & O: & They means the government? \\
& V: & No. I wrote here people.
\end{tabular}

Note: Italics is Russian; bold is English 


\section{L2 Knowledge: A Resource with Limited Value for English Learning}

During their interviews, both participants explained that they draw on their knowledge of L2 French while completing English tasks. However, during the task completion, we did not observe L2 use. Furthermore, rather spontaneously, Vera revealed her perception regarding L2 French knowledge as they were deliberating on the appropriate use of a preposition. Vera expressed her frustration regarding the lack of similarities across her languages: "About prepositions, we cannot compare neither in Russian or in French". This spontaneous reply shows how Vera was aware of differences between her languages and how she felt that the L2 could not always support her learning efforts. This nuances her reported belief that there are some aspects that could be mediated via additional language, but not always.

In summary, we observed that this dyad also used the L1 for numerous functions with more frequent metalinguistic discussions compared to Gabriel and Polixenia. They also appeared to be aware of ways to use their exhaustive repertoire; however, their task performance data did not reveal explicit L2 use. Instead, they activated a selective repertoire, choosing to rely only on their L1 and the target language.

\section{Chucho and Germain}

\section{Reported Beliefs: Plurilingual Repertoire}

Chucho and Germain, the Spanish-speaking participants, had converging perspectives about their language repertoire: both were open to drawing on all forms of knowledge. Chucho explained that, in general, languages share features and the process of learning these in a new language leads to greater awareness of the L1: "I find that there is a great similarity in almost everything. It's true that there is the modal verb, also the preposition. In Spanish, it's the same thing. [...] but when you are learning a new language, you ask questions, 'why' and you see that it's the same thing in Spanish, the same logic". When asked whether they attempted to draw on multiple languages during the task, Chucho explained that he compared English and Spanish and said: "I found very similitudes" and mentioned that he compared and contrasted numerous aspects of his languages (e.g., gender, spelling conventions, conjugations, modals). Germain explained that he did so as well, albeit only for lexis: "For the grammar itself, no, only for the vocabulary. For example, if that concept we say in Spanish like that, how can I say that in English". In turn, when referring to grammar, he explained "We know that Spanish and English are so different and if we try to translate directly, it doesn't work [...] I tried to think in English grammar".

When asked about shuffling between English and French, Germain shared his belief that French vocabulary knowledge was also an asset: "Because we have the concept and the natural word for that concept and we have to learn the word for that concept in the other language". However, he explained that he did not see value in speaking in French during the completion of the task given their learning objectives (English). Similar to Germain, Chucho was open towards drawing on his larger repertoire. He reported that it is important to take advantage of their shared knowledge: "At times, in my opinion, I believe that it is very necessary to explain in French if that is a common language or English if that 
is the common language, certain Spanish words or French words that are difficult to understand".

Overall, they were more aware of the potential benefits associated with having multiple languages in their repertoire. As Chucho explained: "But I think these are tools we can use to learn better. In my opinion, only anglais, only English, it's useful sometimes. But at other times, you have to explain in the mother tongue, in French, or find the word in French if the person doesn't speak Spanish". We now turn to evidence from their interactions that support their use of their repertoire.

\section{Exhaustive Repertoire: Using All Forms of Knowledge}

While completing the writing tasks, we found evidence that they drew on their large knowledge base. In a first instance, it is important to mention that their L1 functions mirrored those previously reported (e.g., generating ideas, metalinguistic explanations). Further, like Gabriel and Polixenia, we found extensive evidence of juxtapositioning structures between the L1 and English. What set this dyad apart was their crosslinguistic discussions which, despite what they said during the interviews, were about form. As illustrated in Excerpt 7, Germain draws a parallel between English and Spanish to show how 'that' and 'que' function in similar ways.

\section{Excerpt 7}

Pointing Out Syntactic Similarities Between English and Spanish

\begin{tabular}{lll}
\hline Line & & Learner-learner interaction \\
\hline 1 & C: & What are designated areas of Montreal. \\
2 & G: & Well, it's not necessary to use the 'that' but, it's more explicit. That Montreal has. \\
3 & C: & That. \\
4 & G: & That Montreal. Here it's the same thing. If you put the 'that'. Yes. You can put it or \\
5 & & leave it without. \\
6 & C: & It's better with the 'that'? \\
7 & G: & It's the same! It's very similar to the Spanish que. What are the areas that the city \\
8 & & has. \\
\hline \multicolumn{2}{l}{ Note: Italics is Spanish; bold is English }
\end{tabular}

In Lines 2 and 5, Germain informs his partner that they can omit the 'that' in this structure. While he does not offer a strong explanation, he draws his partner's attention to the similarities between English and Spanish and produces the Spanish equivalent. Although they did not discuss this further, they produced a corrected form in their revised text, as illustrated in Figure 1.

\section{Figure 1}

Error correction for $Q 4$.

\begin{tabular}{|c|c|}
\hline Error \# & $\begin{array}{l}\text { Discuss the error in English, in French, in العريَّة, in 日本人, or in Română. } \\
\text { Write the corrected sentence in this table: }\end{array}$ \\
\hline 2.2 & When do you think teos snoke. Cannahs is goo o? \\
\hline 2.3 & $\begin{array}{l}\text { What ane the prevention caupagnes. that the City has: } \\
\text { for cannabis consungtwe? }\end{array}$ \\
\hline Q. 4 & $\begin{array}{l}\text { What ane the desigined areas that Montwed has tor } \\
\text { cannabis Consungtiu? }\end{array}$ \\
\hline
\end{tabular}




\section{L2 Knowledge: A Resource for Learning}

In support of their interview data, we also found evidence that they drew parallels between French and English when engaging in crosslinguistic reflections about grammar. In Excerpt 8, Chucho and Germain engage in a lengthy reflective discussion about the constructions 'to think' + infinitive/gerund.

\section{Excerpt 8}

\begin{tabular}{lll}
\multicolumn{3}{l}{ Metalinguistic Reflection While Pointing Out Differences Between English and French } \\
\hline Line & Learner-Learner Interaction \\
\hline 1 & C: & When do you think to smoke... cannabis is good. That is the question. \\
2 & G: & Smoking cannabis. \\
3 & C: & Smoking cannabis. When do you think smoking cannabis... \\
4 & G: & Hum hum. \\
5 & C: & not 'to smoke'. \\
6 & G: & Because you remember that we saw the gerund the last time. \\
7 & C: & The (verb) think requires the gerund. \\
8 & G: & No, that is the second verb. I think that there, it's not the same as in French. \\
9 & C: & There are some that can't. This one does not permit. The ones that are... the \\
10 & & ones that don't have the function. \\
11 & G: & They are called... I know what they are but. \\
12 & C: & Stative. \\
13 & G: & Stative verb. \\
14 & C: & The stative demand infinitives. \\
15 & G: & Alright.
\end{tabular}

Note: Italics is Spanish; bold is English

In Line 6, Germain reminds his partner that they recently covered the gerund in their classes and Chucho confirms the rule in Line 7. Germain then comments on the fact that this rule differs in French; however, they do not discuss this further. Their crosslinguistic metalinguistic discussion continues in which they explain the rule for stative verbs, a discussion primarily conducted in Spanish. These excerpts show the fluid boundaries between languages. Further, as argued by Germain, learning an L3 also increases their awareness of the other languages in their repertoire, including their L1: "I realized I learned a lot of things in Spanish, studying English and French [...] To compare to Spanish, the grammar, the pronunciation, how complex. A lot of things, I realized".

In conclusion, this dyad believed that their exhaustive plurilingual repertoire benefited their language learning experience. In the case of Chucho, his exhaustive repertoire served lexical and grammatical functions whereas Germain limited its value to lexical reflections; however, we found evidence that discussions emerged with respect to grammar also during their interactions.

\section{Synthesis}

To recapitulate, we found that all participants drew extensively on their L1 to complete the collaborative writing task with the $\mathrm{L} 1$ appearing to serve a range of common functions. Furthermore, none of the dyads carried out discussions in French, their shared L2, and only infrequent references to their knowledge of French were reported and 
observed. A visual summary of the more frequent patterns associated with each dyad is presented in Figure 2.

Figure 2

Synthesis of Each Dyad's Patterns of Interaction

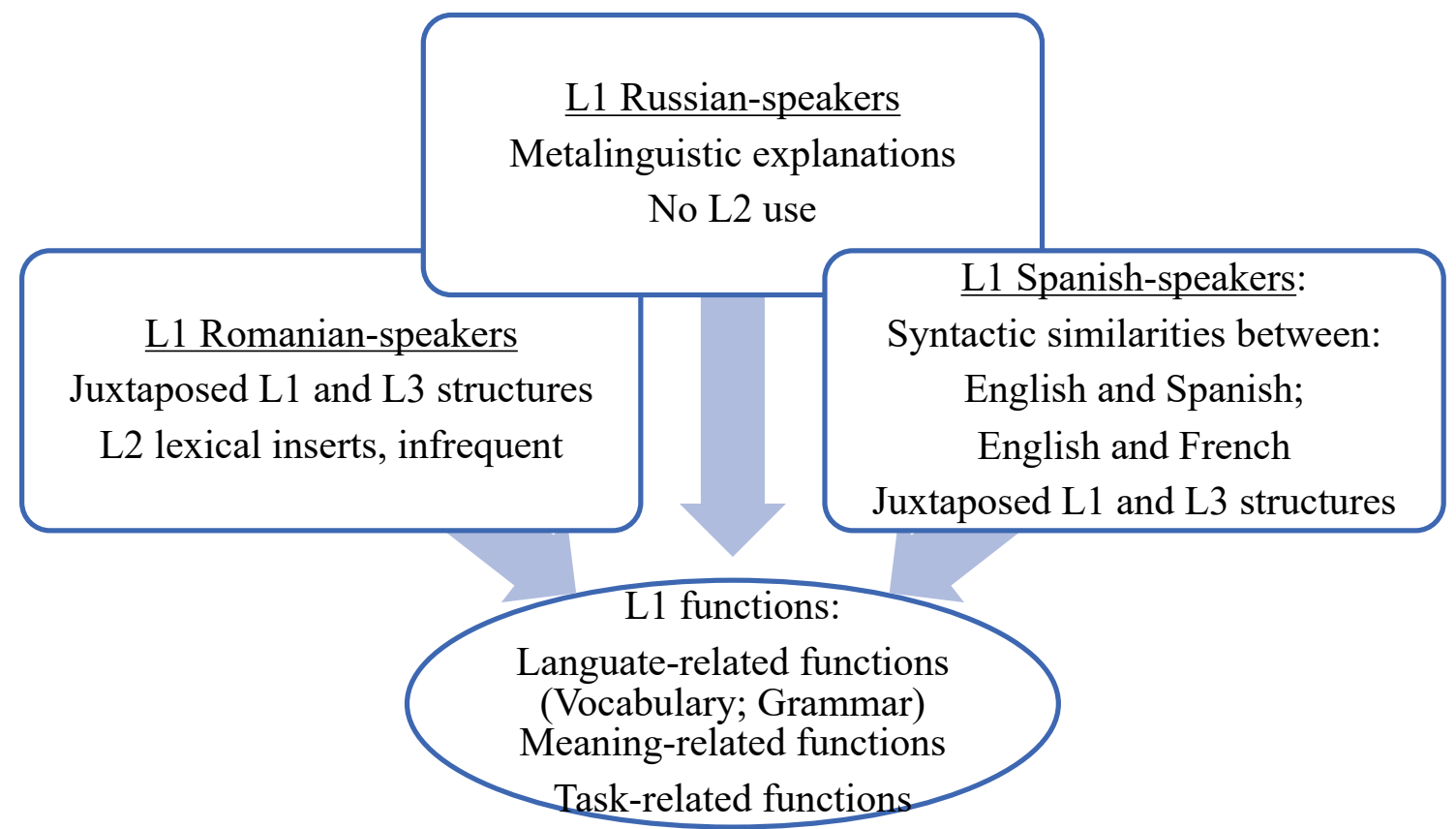

\section{Impact of Context on Willingness to Use Multiple Linguistic Resources}

The present study was carried out in a laboratory setting and we intentionally formed dyads who shared languages. During the interviews, the participants drew our attention to the context and its impact on their use of their larger linguistic repertoire. The six participants shared that knowledge of multiple languages was perceived as an asset for long-term educational goals, as well as for social and professional functions. For instance, Chucho explained that he needs multiple languages to pursue his academic goals: "English, yes, for reading comprehension but I want to do my doctorate in Spanish and the second language will be French because it's in the social sciences. The third, it's English, for some documents, many books, for references and that is the choice I made". When discussing social interactions, Germain explained: "I am trying to become used to change the language because I think also this is a very good skill, to be able to switch to French, to English, to Spanish, without being confused". Finally, to achieve educational goals, there was agreement that it is essential to be able to use multiple languages. Polixenia explained how in French-speaking Canada, French is not the only linguistic resource that is needed: "In many occasions, we need to speak in English too. When I participate at salon d'emploi, every time the person who was there asked me 'Do you speak English too?' [...]. And then I know it's very important to speak English too, in Canada. It's necessary".

However, in formal classroom contexts, the participants intentionally distanced themselves from peers who shared their linguistic repertoire, a form of linguistic distancing. The participants felt it best to position themselves in such a way that they were 
unable to use their dominant language because they do think that a monolingual approach seems better to learn an additional language. Gabriel said: "Every time, I went in my ... English or French class, every time when I meet a Romanian student, I try to stay away from them". They are open to working with speakers of French, however. Germain said: "If he asked me something (in Spanish), I respond in Spanish also. This is why I try to sit far from the people who speak Spanish to force me to speak English or French". In sum, these statements support the idea that these learners have adopted unconsciously monolingual approaches and that they may not comprehend how their entire linguistic repertoire could support their language learning efforts.

\section{Discussion}

The present study contributes new empirical evidence of plurilingual learners' perceptions towards the use and actual use of their linguistic repertoire during collaborative writing tasks. Three participants were less open to using additional languages when learning a new language, a finding that appears to be more closely aligned with monolingual pedagogies. The other three expressed the belief that all languages are tools to be used to support their learning. Differences in learners' perceptions towards the value of L1 use have been reported with L2 learners (Rolin-Ianziti \& Varshney, 2008; Storch \& Wigglesworth, 2003) and plurilingual learners (Kim et al., 2020; Payant, 2020). While there is overall consensus that the L1 plays an important role in learning and in promoting group interpersonal functions (Hafner et al., 2015), it has been reported in foreign language settings that some learners find L1 use to be illogical, wrong, useless (Mora Pablo et al., 2011). The difference in contexts is an important variable to consider since language classrooms are, for some, the only opportunities to hear and produce the target language. Additionally, the status of the target language and the learners' repertoire of languages could also influence how they perceive L1 use.

With regards to their actual practices, each participant shuffled between their L1 and the target language spontaneously and regularly during the main writing tasks, a finding which does not align with their reported beliefs. This may be due to the task design which encouraged the use of other languages as well as the fact that dyads were formed with learners sharing the same linguistic repertoires. We did observe, however, that the specific functions of the L1 were congruent with previous research with L2 and L3 learners (Al Masaeed, 2016; Antón \& DiCamilla, 1998; Ma, 2019; Payant \& Kim, 2015; Storch \& Wigglesworth, 2003; van Weijen et al., 2009). The place for the L2 in L3 learning, however, is less clear. The Romanian- and Russian-speaking L1 learners tended to activate a selective repertoire: L2 French was not observed during their interactions. In turn, the Spanish-speaking participants tended to make more use of their exhaustive repertoire: they made both L1-L3 and L2-L3 connections spontaneously, although, the L2-L3 connections were not that frequent. Future research may explore the functions of all languages used during collaborative tasks where learners either share the same L1 or the same L2. This would allow us to better understand the contributions of various languages.

The finding that the L2 played a much smaller role than the L1 during learner interactions mirrors those from Payant and Kim (2015) but comes in stark contrast with Kim et al., (2020) who found that one of their two dyads only drew on their shared L2 and L3. L1 was virtually non-existent. There is robust evidence that all languages in a repertoire are active in our minds; however, which language to use to support interaction is 
a personal choice that may also be influenced by how we perceive the languages that comprise our repertoire. In other words, learners have agency to establish their own rules and to choose the language(s) that will help them attain their context-specific goals, inside and outside the classroom (Lüdi \& Py, 2009). Agency is a "complex, dynamic system" (Mercer, 2011, p. 435) and it "has to be understood as situated and contextual" (Marshall $\&$ Moore, 2018, p. 24). Contextual factors may include the target languages and their relative status in society, the age of the participants, and the learning contexts, to name a few. These differences across the participants in activating the languages that comprise their repertoire also demonstrate how linguistic repertoires "can be seen as a space both of restrictions and potentialities" (Busch, 2012, p. 509). Although learners may feel empowered to activate their entire repertoire or a subset of their languages, it is important that we guide learners in ways to use their repertoire of language to maximize learning opportunities through modelling and by implementing tasks that include input in different languages (Dault \& Collins, 2016; Galante, 2019). We must also help students understand that the separation of languages is a social construct and that this division between named languages is not real. While there is growing interest in implementing plurilingual approaches with adult learners studying majority languages (Galante, 2020; Kim et al., 2020; Marshall, 2019; Payant, 2020; Piccardo, 2013; Taylor \& Snoddon, 2013; Woll, 2020), we must also include the voices of students from minority language backgrounds and of younger learners in these types of studies to identify when plurilingual approaches truly benefit learners' experiences (Payant \& Galante, 2022).

In the present study, these adult participants were encouraged to rely on their entire repertoire during tasks. Task materials promoted language use and instructions explicitly encouraged them to establish crosslinguistic links, especially during the error correction task. Yet, we did not find robust evidence that learners explicitly drew on their exhaustive repertoire (i.e., limited French use) nor did we find evidence that they actually compared and contrasted structures or vocabulary in systematic ways across their linguistic resources. In other words, comparisons were scarce, sporadic, and quite brief. It was quite surprising that L2 French did not play a more important role given the context in which this study was conducted, namely a francophone institution. We hypothesize that the limited explicit use of French was due to the shared L1 which made it more natural for participants to rely on their dominant, shared repertoire. However, it could also be due to years of being told: "target language use only". These monolingual pedagogies form a part of learners' DNA: Learners may not actually know that languages are tools that can be used to scaffold the learning process. In order to break this pattern and develop new forms of learning that celebrate plural identities, we need to engage learners in tasks that welcome the use of their plurilingual tools. Specifically, there is a need to model crosslinguistic reflections and to train learners to systematically engage in these types of comparisons. We believe that learners may not know how to engage their resources, even when reminded to use their entire repertoire, and future research should examine the impact of training learners to work with these symbolic tools for specific purposes. It would also be important to work with pre-service and in-service teachers on developing and implementing tasks that help their learners understand and value their plurilingual repertoires, for example, linguistic self-portraits (Galante, 2018; Prasad, 2014) and crosslinguistic comparisons (Dault \& Collins, 2017). The current task design can also be used in a classroom setting or modified to include articles in multiple languages for students to read and integrate into their writing. 
Finally, we conclude that participants' activation of an exhaustive or selective repertoire was also influenced by the perceived typological distance between languages. Specifically, the Russian- and Romanian-speaking participants explained that comparing grammatical notions was not possible given the distance between their L1 and the target language. The perceived degree of similarity between languages can be a factor influencing the ways learners draw on their languages, as previously mentioned by Moore and Gajo (2009). In this context, however, the participants tended to disagree in terms of the potential to draw parallels between English and French with some finding these two languages to be too different. If the activation of multiple languages is in fact "highly dependent on [...] learners' perceptions of linguistic distance between their languages" (Moore \& Gajo, 2009, p. 144), it is important to engage learners in discussions and reflections about the potential similarities between the different languages. These findings further support the importance of modelling crosslinguistic reflections (Dault \& Collins, 2016; Galante, 2019) and pushing learners to look for connections that, on the surface, may not be evident. This may help learners become more aware of similarities between languages and possibly increase their awareness of how their knowledge can become a useful resource (Leonet et al., 2020, p. 56).

\section{Conclusion}

Nearly twenty years ago, Lemke (2002) asked: "Could it be that all our current pedagogical methods in fact make multilingual development more difficult than it need be, simply because we bow to dominant, political and ideological pressures to keep languages pure and separate" (p. 85). We believe that the answer to this question is yes. We also believe that the impact of the monolingual views on language education that have dominated the field of language teaching will continue to influence bi-/multilingual learners' perceptions towards plurilingual approaches to language learning unless they are encouraged to exercise their plurilingual competence. The plurilingual repertoire is a fluid construct and individuals move within this repertoire to meet their needs, in light of the context, the interlocutors, and the task (Coste et al., 2009; Moore \& Gajo, 2009). In order to support language learners and move towards plurilingual pedagogies, we must enable them to identify the plurilingual resources at their disposal and demonstrate how they can be used in support of language learning and communication.

Correspondence should be addressed to Caroline Payant.

Email: payant.caroline@uqam.ca

\section{Note}

${ }^{1}$ Participants' comments were not modified for grammatical accuracy.

\section{Acknowledgements}

The authors gratefully acknowledge the support of the Social Sciences and Humanities Research Council (SSHRC) Insight Development Grants competition, 430-2018-00752. We would like to thank the editors Drs. Eva Kartchava and Michael Rodgers and their editorial assistant Alex Ross. 


\section{References}

Al Masaeed, K. (2016). Judicious use of L1 in L2 Arabic speaking practice sessions. Foreign Language Annals, 49(4), 716-728. https://doi.org/10.1111/flan.12223

Ançã, M. H., \& Alegre, T. (2003). A consciencialização linguística em português língua materna e em alemão língua estrangeira. Palavras, 24, 31-39.

Angelovska, T. (2018). Cross-linguistic awareness of adult L3 learners of English: a focus on metalinguistic reflections and proficiency. Language Awareness, 27(1-2), 136152. https://doi.org/10.1080/09658416.2018.1431243

Antón, M., \& DiCamilla, F. (1998). Socio-cognitive functions of L1 collaborative interaction in the L2 classroom. Canadian Modern Language Review, 54(3), 314-342.

Armand, F. (2012). Enseigner en milieu pluriethnique et plurilingue : place aux pratiques innovantes! Québec Français, 167, 48-50. https://doi.org/67710ac

Busch, B. (2012). The linguistic repertoire revisited. Applied Linguistics, 33(5), 503-523. https://doi.org/10.1093/applin/ams056

Canagarajah, S. (2011). Codemeshing in academic writing: Identifying teachable strategies of translanguaging. The Modern Language Journal, 95(3), 401-417. https://doi.org/10.1111/j.1540-4781.2011.01207.x

Castellotti, V., \& Moore, D. (2005). Répertoires pluriels, culture métalinguistique et usages d'appropriation. Les Cultures Éducatives et Linguistiques dans l'enseignement des Langues, 107-132.

Cenoz, J., \& Gorter, D. (2013). Towards a plurilingual approach in English language teaching: Softening the boundaries between languages. TESOL Quarterly, 47(3), 591599. http://www.jstor.org/stable/43268035

Coste, D., Moore, D., \& Zarate, G. (2009). Plurilingual and pluricultural competence. https://doi.org/10.1080/14790710902846723

Cummins, J. (2007). Rethinking monolingual instructional strategies in multilingual classrooms. Canadian Journal of Applied Linguistics, 10, 221-240. https://doi.org/10.1007/BF02045874

Dault, C., \& Collins, L. (2016). L'utilisation des langues connues des apprenants en classe de français langue seconde. Canadian Modern Language Review, 72(4), 504-529. https://doi.org/10.3138/cmlr.3387

Dault, C., \& Collins, L. (2017). Comparer pour mieux comprendre : perception d'étudiants et d'enseignants d'une approche interlangagière en langue seconde. Language Awareness, 26(3), 191-210. https://doi.org/10.1080/09658416.2017.1389949

Galante, A. (2018a). Examining Brazilian foreign language policy and its application in an EFL university program: Teacher perspectives on plurilingualism. In J. Crandall \& K. M. Bailey (Eds.), Global Perspectives on Language Education Policies (pp. 46-55). Routledge.

Galante, A. (2018b). Plurilingualism in linguistically diverse language classrooms:

Respecting and validating student identity. In V. Kourtis-Kazoullis, T. Aravossitas, E. Skourtou, \& P. Pericles Trifonas (Eds.), Interdisciplinary Research Approaches to Multilingual Education (pp. 65-78). Routledge. https://doi.org/10.4324/9781351170086

Galante, A. (2019). “The moment I realized I am plurilingual”: Plurilingual tasks for creative representations in EAP at a Canadian university. Applied Linguistics Review, 
$O(0), 1-30$. https://doi.org/10.1515/applirev-2018-0116

Galante, A. (2020). Pedagogical translanguaging in a multilingual English program in Canada: Student and teacher perspectives of challenges. System, 92. https://doi.org/10.1016/j.system.2020.102274

Galante, A., Okubo, K., Cole, C., Elkader, N.A., Carozza, N., Wilkinson, C., Wotton, C. and Vasic, J. (2020), "English-only is not the way to go": Teachers' perceptions of plurilingual instruction in an English program at a Canadian university. TESOL Journal. doi:10.1002/tesq.584

García, O., \& Otheguy, R. (2020). Plurilingualism and translanguaging: commonalities and divergences. International Journal of Bilingual Education and Bilingualism, 23(1), 17-35. https://doi.org/10.1080/13670050.2019.1598932

Grosjean, F. (2008). Studying bilinguals. Oxford University Press.

Gunnarsson, T. (2019). Multilingual students' use of their linguistic repertoires while writing in L2 English. Lingua, 224, 34-50. https://doi.org/10.1016/j.lingua.2019.03.007

Hafner, C. A., Li, D. C. S., \& Miller, L. (2015). Language choice among peers in projectbased learning: A Hong Kong case study of English language learners' plurilingual practices in out-of-class computer-mediated communication. Canadian Modern Language Review, 71(4), 441-470. https://doi.org/10.3138/cmlr.2712

Haukås, Å. (2016). Teachers' beliefs about multilingualism and a multilingual pedagogical approach. International Journal of Multilingualism, 13(1), 1-18. https://doi.org/10.1080/14790718.2015.1041960

Jessner, U. (2008). Teaching third languages: Findings, trends and challenges. Language Teaching, 4l(01), 15-56. https://doi.org/10.1017/S0261444807004739

Kim, Y., Cho, H., \& Ren, H. (2020). Collaborative writing tasks in an L3 classroom: Translanguaging, the quality of task outcomes and learners' perceptions. In C. Lambert \& R. Oliver (Eds.), Using Tasks in Second Language Teaching: Practice in Diverse Contexts (pp. x-x). Bristol, UK: Multilingual Matters.

Lemke, J. (2002). Language development and identity: Multiple timescales in the social ecology of learning. In C. Kramsch (Ed.), Language Acquisition and Language Socialization (pp. 68-87). London, England: Continuum.

Leonet, O., Cenoz, J., \& Gorter, D. (2020). Developing morphological awareness across languages: Translanguaging pedagogies in third language acquisition. Language Awareness, 29(1), 41-59.

Lin, A. (2013). Toward paradigmatic change in TESOL methodologies: Building plurilingual pedagogies from the ground up. TESOL Quarterly, 47(3), 521-545. https://doi.org/10.1002/tesq.113

Lüdi, G., \& Py, B. (2009). To be or not to be ... a plurilingual speaker. International Journal of Multilingualism, 6(2), 154-167. https://doi.org/10.1080/14790710902846715

Ma, L. P. F. (2019). Examining the functions of L1 use through teacher and student interactions in an adult migrant English classroom. International Journal of Bilingual Education and Bilingualism, 22(4), 386-401. https://doi.org/10.1080/13670050.2016.1257562

Marshall, S. (2019). Understanding plurilingualism and developing pedagogy: Teaching in linguistically diverse classes across the disciplines at a Canadian university. 
Language, Culture and Curriculum. https://doi.org/10.1080/07908318.2019.1676768

Marshall, S., \& Moore, D. (2018). Plurilingualism amid the panoply of lingualisms: addressing critiques and misconceptions in education. International Journal of Multilingualism, 15(1), 19-34. https://doi.org/10.1080/14790718.2016.1253699

Marshall, S., Moore, D., James, C. L., Ning, X., \& Dos Santos, P. (2019). Plurilingual students' practices in a Canadian university: Chinese language, academic English, and discursive ambivalence. TESL Canada Journal, 36(1), 1-20.

Mercer, S. (2011). Understanding learner agency as a complex dynamic system. System, 39(4), 427-436. https://doi.org/10.1016/j.system.2011.08.001

Mieszkowska, K., \& Otwinowska-Kasztelanic, A. (2015). Is A2 in German better than B2 in French when reading Danish? The role of prior language knowledge when faced with an unknown language. In G. De Angelis, U. Jessner, \& M. Kresić (Eds.), Crosslinguistic influence and crosslinguistic interaction in multilingual language learning (pp. 199-230). Bloomsbury Publishing.

Moore, D., \& Gajo, L. (2009). Introduction-French voices on plurilingualism and pluriculturalism: Theory, significance and perspectives. International Journal of Multilingualism, 6(2), 137-153. https://doi.org/10.1080/14790710902846707

Mora Pablo, I., Lengeling, M. M., Rubio Zenil, B., Crawford, T., \& Goodwin, D. (2011). Students and teachers' reasons for using the first language within the foreign language classroom (French and English) in Central Mexico. Profile Issues in Teachers' Professional Development, 13(2), 113-129.

Oliveira, A. L., \& Ançã, M. H. (2009). "I speak five languages”: Fostering plurilingual competence through language awareness. Language Awareness, 18(3-4), 403-421. https://doi.org/10.1080/09658410903197355

Payant, C. (2018). Effects of L3 learner proficiency and task types on language mediation: A sociocultural perspective. In Mohammad Javad Ahmadian \& M. del P. García Mayo (Eds.), Recent perspectives on task-based language learning and teaching (pp. 99-120). De Gruyter Mouton.

Payant, C. (2020). Exploring multilingual learners' writing practices during an L2 and an L3 individual writing task. Canadian Modern Language Review/Revue canadienne des langues vivantes.76(4), 313-334.

Payant, C. \& Galante, A. (2022). Plurilingualism and translanguaging: Pedagogical approaches for empowerment and validation. (Eds). Special Issue TESL Canada Journal.

Payant, C., \& Kim, Y. (2015). Language mediation in an L3 classroom: The role of task modalities and task types. Foreign Language Annals, 48(4), 706-729. https://doi.org/10.1111/flan.12161

Payant, C., \& Kim, Y. (2019). Impact of task modality on collaborative dialogue among plurilingual learners: a classroom-based study. International Journal of Bilingual Education and Bilingualism, 1-14. https://doi.org/10.1080/13670050.2017.1292999

Piccardo, E. (2013). Plurilingualism and curriculum design: Toward a synergic vision. TESOL Quarterly, 47(3), 600-614. https://doi.org/10.1002/tesq.110

Piccardo, E. (2019). "We are all (potential) plurilinguals": Plurilingualism as an overarching, holistic concept. OLBI Working Papers, 10, 183-204. https://doi.org/10.18192/olbiwp.v10i0.3825

Rolin-Ianziti, J., \& Varshney, R. (2008). Students' views regarding the use of the first 
language: An exploratory study in a tertiary context maximizing target language use. Canadian Modern Language Review, 65(2), 249-273. https://doi.org/10.3138/cmlr.65.2.249

Storch, N., \& Aldosari, A. (2013). Pairing learners in pair work activity. Language Teaching Research, 17(1), 31-48.

Storch, N., \& Wigglesworth, G. (2003). Is there a role for the use of the L1 in an L2 setting? TESOL Quarterly, 37(4), 760-770. https://doi.org/10.2307/3588224

Taylor, S. K., \& Snoddon, K. (2013). Plurilingualism in TESOL : Promising controversies. TESOL Quarterly, 47(3), 439-445. https://doi.org/https://www.jstor.org/stable/43268027

Tullock, B. D., \& Fernández-Villanueva, M. (2013). The role of previously learned languages in the thought processes of multilingual writers at the Deutsche Schule Barcelona. Research in the Teaching of English, 47(4), 420-441. https://doi.org/https://eric.ed.gov/?id=EJ1013768

van Weijen, D., van den Bergh, H., Rijlaarsdam, G., \& Sanders, T. (2009). L1 use during L2 writing: An empirical study of a complex phenomenon. Journal of Second Language Writing, 18(4), 235-250. https://doi.org/10.1016/j.jslw.2009.06.003

Woll, N. (2020). Towards crosslinguistic pedagogy: Demystifying pre-service teachers' beliefs regarding the target-language-only rule. System, 92 .

https://doi.org/10.1016/j.system.2020.102275 